\title{
Environmental monitoring and microclimatic control strategies in "La Specola" museum of Florence
}

Fabio Sciurpi ${ }^{a}$, Cristina Carletti $^{a}$, Gianfranco Cellai $^{a}$, Leone Pierangioli ${ }^{b}$,

a Department of Industrial Engineering, University of Florence, via San Niccolò 93, Firenze 50125, Italy; E-mail: fabio.sciurpi@unifi.it, cristina.carletti@unifi.it, gianfranco.cellai@unifi.it,

b Department of Architecture, University of Florence, Italy , via San Niccolò 93, Firenze 50125, Italy; E-mail: leone.pierangioli@unifi.it

\begin{abstract}
This work presents the results of the environmental monitoring of some rooms of the "La Specola" Museum in Florence, affected by significant overheating problem in summer mainly due to the absence of efficient solar shadings. The elaboration and analysis of the microclimatic data have been carried out according to the Italian Standard UNI 10829 and the Performance Index of the most important thermo hygrometric parameters has been calculated and assessed. This analysis shows that temperature and RH conditions were not reasonably acceptable for the preservation of the kind of objects exhibited. In order to reduce this problem, solar gain control solutions (shadings and solar control glasses) has been analysed with a dynamic thermal simulation tool for two sample rooms, as a possible solution to improve architectural integration with the historical context. In order to reduce the risk of damage, the evaluation of different strategies has been expressed in terms of the reduction of energy need for space cooling and in terms of the ability to control dry bulb temperature values. The results can be extended to several historical buildings, where large windows and skylights cause high energy consumption and poor indoor environmental conditions that can cause damage to the artefacts.
\end{abstract}

Key words Microclimate for historical Museums, Indoor environmental monitoring, Preventive conservation, Solar radiation control strategies, Dynamic simulation

\section{Introduction}

In museums several interactions occur between the indoor environmental conditions and the objects exposed. These interactions, if not properly supervised and limited may cause irreversible process of exhibits degradation. Microclimate plays a fundamental role in the deterioration process of the exhibit objects that can be strongly affected by the values of temperature and relative humidity $(\mathrm{RH})$, and their time and space fluctuations. Sudden time changes and intense space variations of air temperature and relative humidity are supposed to induce stresses to several materials: this in turn creates cumulative and irreversible alterations of the physical and chemical properties which could accelerate the deterioration process [1]. As a matter of fact, in the last fifteen years, the attitude is oriented to preventive conservation, that is a combination of actions directed to reduce the risk of degradation of the exposed object and to identify optimal environmental conditions to show the object in the safest way. It implies both "passive" techniques, aimed to minimize the potential damage to the object from the exhibition environment, and environmental monitoring and management directed to minimize variations of indoor parameters and to reduce impacts from outdoor. In the absence of a heating, ventilating and air conditioning system showcases are of 
key relevance in the conservation and are widely used in not HVAC equipped museums; in general they work as a filter against environmental attacks due to microclimate variations, chemical pollution and action of micro-organism; moreover, they offer a protection against vandalism, robberies and any direct damage that could come from visitors [2] [3] [4]. In order to define and asses proper passive techniques of conservation, microclimatic monitoring of museum rooms and showcases is necessary to assess the museum environment suitability to conserve exhibits and to plan any action required to reduce degradation risk [5] [6]. Italian and European technical regulations about cultural heritage conservation [7] [8] establish guidelines and methods to measure indoor temperature, humidity and lighting level. Especially in historical buildings turned into museums is very necessary to carry out a compromise between objects conservation, public fruition and visitors comfort [9]. Main issues related to exposed object deterioration depending on absolute value of temperature and $\mathrm{RH}$ as well as their alteration in time can be classified in physical (dimensional and shape variation of objects), chemical (chemical reactions) and microbiological problems for the exhibits (microorganism growth). Depending on the type of object exposed, expansion or contraction due to temperature variation can be relevant as well as those due to $\mathrm{RH}$ variation. In general, even if the optimal microclimatic conditions have been fixed for the most important categories, however it is always difficult to collect information about "the history of deterioration" of the different objects and to therefore establish the importance of the deterioration speed related to the deviation from the optimal established values. In Italy, many museums are placed in historical buildings and are not equipped with HVAC systems or sealed showcases. In particular, in the Florence district are placed many different museums; most of all $(90 \%)$ are placed in historical buildings so that their restoration, improvement, safety and accessibility is really difficult to achieve and maintain. Florence museums conditions are very different and in almost $25 \%$ of museums poor conditions are pointed out (possible water infiltration, low windows performances, absence of lighting and solar control systems, poor thermal performance of the building envelope). Widespread are heating systems with radiators or fan coils and $33 \%$ of museums is unprovided of any heating system.

\section{Description of "La Specola" Museum of Florence}

One of the most important Museum of Florence is "La Specola", situated in Palazzo Torrigiani; it can be considered the first European scientific museum opened to the public. It was inaugurated, under the name of Royal Museum of Physics and Natural History, on February 21, 1775, at the wish of Peter Leopold of Lorraine, Grand Duke of Tuscany, who had expressly ordered the reorganization of the Medici collections. The first director of the museum, Felice Fontana, initially organized the museum based on the existing scientific material inventoried in 1763 by Giovanni Targioni Tozzetti, and then continued to enrich it with new acquisitions. At the same time, a collection of anatomical wax models was created, which illustrate the entire human body in all its details. The Museum has always been known as "La Specola" because of the presence in the building of a small tower used as an astronomical observatory, established in 1789 and operative for almost a century. "La Specola" zoological collections are rich, but only a small portion of the over three million specimens is visible to the public; the rest constitutes research material for specialists. Most of the specimens displayed in the halls date to between the second half of the 1800s and the first decades of the 1900s, and almost all of them were collected during scientific expeditions organize by the Museum. The Museum is open from Thursday to Sunday (01/10-31/05: 09.30-16.30; 01/06-30/09: 10.30-17.30). On Monday ordinary maintenance is carried out. Inside "La Specola" Museum are collected objects with different conservative requirements; the rooms contain showcases, of great historic and artistic value, in which very different specimen are exposed, such as: Diorama, Protozoa, Mollusca, Insects, Worms, Echinoderms, Carnivores, "Count of Turin" hunting trophies, Rodents, Cetaceans, Monkeys, Birds, Reptiles, Fishes, Anatomic waxes, etc. In particular, anatomical waxes are mostly vulnerable to high temperature values while wooden showcases particularly suffer from temporal RH variations 
that can cause their dimensional alterations. For their safe exhibition anatomical waxes are securely coupled to showcases so any shift of the wooden support structure have repercussions on the exposed object and can cause its damage. For this reason, when the first temperature control system has been install in the wax section, many conservative problems occurred, first of all the showcases dimensional variations, caused by the decrement of RH values lower than the values the showcases get historically accustomed. This phenomenon provokes the breaking both of the showcases veneer and of the parts of the waxes connected to the showcases because of their different water vapor adsorption. Since than, the showcases and the exhibit waxes have been restored and now are balanced with the new microclimatic environment. As for the zoological exhibits, they are particularly sensible to high temperature values that can cause biological growth and activate putrefaction. RH variations are particularly important for the mammals exhibited that have an inner filling made of gypsum instead of straw; this filling presents a different behavior then the animal skin and can cause its break due to high temperatures that determine a quick and uncontrolled reduction of RH values in summer periods. "La Specola" is a non air conditioned museum; only in the waxes section (rooms XXV - XXXIV) a heat pump system with ceiling fan coils was installed in the ' 80 s to maintain indoor temperature between 20 and $22^{\circ} \mathrm{C}$; air temperature control system consist of simply thermostat placed in every room. Artificial lighting in the Museum is guaranteed by discharge lamps that are turned on for all the opening hours, in some rooms there is also artificial lighting inside showcases (discharge lamps and LED).

\section{Environmental monitoring campaign: analysis, results and discussion}

An experimental monitoring system has been installed in the Zoology "La Specola" Section of the Natural History Museum of Florence in order to investigate and control the indoor microclimatic conditions as well as to point out damage causes for the objects ex posed (Figure 1). Fixed data loggers (resolution: $0,1^{\circ} \mathrm{C} / 0,1 \%$; accuracy: $\pm 0,5^{\circ} \mathrm{C} / \pm 2 \%$ ) has been used in the Museum to collect values of dry bulb temperature $(\theta)$ and relative humidity $(\mathrm{RH})$ with fifteen-minute time step. The loggers, placed in 16 rooms and inside 4 representative showcases, send the signal every 15 minutes to a master connected to a PC thanks to a LAN network so that the system can immediately collect the measures, even when great distances are involved. Recordings of each data logger are displayed in the bookshop's PC and in the museum manager's PC, in order to perform a real time control of the measured environmental parameters. The external data logger, protect from the solar radiation, is located in an internal courtyard. As for the conservation, optimal parameters can be defined both by the curators and by technical documents and UNI standards, such as DM 10.05.2001 [10], UNI 10829 [7] and UNI EN 15757 [8]; these parameters can be defined on the basis of climatic history of the exhibits, their material and structural characteristics. Thanks to important new indexes such as "cumulative frequency" and "deviation indicator" [7], and "performance index" [1], it is possible to assess the quality of the museum environment. From the knowledge of the cumulative frequency and of the deviation indicator of the monitored values, the performance index (PI) can be defined; this index expresses a brief evaluation on the quality of the indoor environment in relation to the conservation of the object contained in it. It represents the percentage of time during which the measured parameters fall within their ranges considered as "acceptable" for the conservation of works of art exhibited. Monitoring campaign in the Museum started on October 2011 and is still in progress. In the present work, results obtained during one year measurements are analy sed and discussed. Data from March 2012 until March 2013 were collected and processed, according to the methods for elaboration and analysis of data suggested by UNI 10829. For each room and showcase monitored the temporal profiles were evaluated, the frequency distributions and cumulative frequency distribution of temperature and $\mathrm{RH}$ were examined. Minimum and maximum values of temperature and $\mathrm{RH}$, daily gradients of temperature $(\Delta \theta 24)$ and $\mathrm{RH}(\Delta \mathrm{RH} 24)$ were also evaluated. Further on, as indicator of the quality of the indoor environment the PI was calculated. In this work are presented the results of the in field thermo hygrometric measurements for some typical rooms (XVI, XIX, XXVIII), chosen on the basis of the following criteria: conditioned or non conditioned rooms, 
presence of windows or skylights, external walls, relevance of the objects exposed. Because of most of the objects are exhibited inside museum showcases, monitoring results in two typical showcases, inside room XIX (XIXs) and XXVIII (XXVIIIs), were reported and compared. Rooms XVI and XIX are without conditioning system, while in room XXVIII only air temperature is controlled throughout the year by fan-coils. In Table 1 main characteristics or the analysed environments are reported. The results are analysed with the aim to point out main problems for the object conservation. On the basis of the characteristics of the objects, the Museum Conservators accepted values for the conservation of artefacts are: $15^{\circ} \mathrm{C}<\theta<24^{\circ} \mathrm{C} ; 40 \%<\mathrm{RH}<60 \% ; \Delta \theta 24<1.5^{\circ} \mathrm{C} ; \Delta \mathrm{RH} 24<5 \%$. For one year monitoring, the time profiles of mean daily temperature and RH measured in room XVI, XIX, XXVIII are presented and compared with the corresponding outdoor values (OUT) and the accepted values (Figure 2 and 3). The analysis of the microclimatic parameters measured shows that temperature and $\mathrm{RH}$ conditions, during the monitoring period, were not reasonably acceptable for the preservation of the kind of objects exhibited. In Table 2, for the year monitored, maximum daily gradient of temperature $(\Delta \theta 24$ max $)$ and $\mathrm{RH}(\Delta \mathrm{RH} 24$ max $)$ for the analysed environment are reported, together with the PI of the thermo hygrometric parameters analysed $(\theta, \mathrm{RH}, \Delta \theta 24, \Delta \mathrm{RH} 24)$. From data collected it is clear that the temperature and RH trend is similar for the uncontrolled rooms (XVI and XIX) and follows the outdoor climate, although very dampened in sudden hourly and daily changes. In spring and autumn indoor temperature and $\mathrm{RH}$ are within the recommended range, whereas in summer and in winter temperature is respectively above and below the limits, with an annual PI $\theta$ of $32 \%$, and $\mathrm{RH}$ is respectively below and above the limits, with an annual PIRH of $47 \%$. Regarding the room XXVIII, the fan coils system keeps constant temperature values and reduces indirectly $\mathrm{RH}$ variations, except when the system is not working: in these moments the values are aligned to those of the other rooms, with consequent maximum daily gradient of temperature of $6.6^{\circ} \mathrm{C}$. From the Figure 2 it is evident the stabilization of the temperature in the room XXVIII from the moment the fan coils were replaced (end of June 2012); nevertheless variations in the temperature values can also be due to the presence of an unlocked thermostat that can be easily reached by visitors. Faced with an external $\Delta \theta 24$ max of $22.6^{\circ} \mathrm{C}$, the maximum daily temperature variation occurs in room XIX $\left(4.7^{\circ} \mathrm{C}\right)$ which is the most exposed to outside weather conditions having three external walls with large windows and a large roof. The PI $\Delta \theta 24$ is very low for the rooms monitored except for the room XXVIII, which is equal to $63 \%$, thanks to the climatic control system present. Faced with an external $\triangle \mathrm{RH} 24$ max of $63 \%$, it is clear the stabilization of this parameter inside the exhibition rooms, and PI $\triangle$ RH24 is high (from $63 \%$ to 67\%). In Figures 4 and 5, respectively for the coldest and hottest week of the year monitored, the time profiles of temperature measured in room XVI, XIX, XXVIII and inside the two showcases (XIXs and XXVIIIs) are compared with the corresponding outdoor values (OUT). From the diagrams is clearly visible the influence of the external climate on the temperature trend within the rooms. Particularly significant are the values of temperature inside the showcase inside the room XIX (XIXs) that are maintained in winter below those of the room with a maximum value of about $3^{\circ} \mathrm{C}$ in February; as a matter of fact being this showcase huddled on a not insulated and North oriented external wall, the lack of thermal insulation of these is reflected in lower temperatures inside the display case. From the Figure 5 we can see that in summer the un controlled rooms temperatures and the showcase temperatures tend to coincide, following the outdoor temperature trend, with very noticeable damping of the daily changes. In Figures 6 and 7 the time profiles of RH measured in room XIX and XXVIII are compared with those of the corresponding showcases (XIXs and XXVIIIs). Although the showcases are not sealed, they reduce RH variations respect those of the rooms and guarantee a damping of $\mathrm{RH}$ changes greater then temperature ones. The RH trend inside the cases is related to the indoor temperature trend rather than to the outdoor RH variations. From the comparison between Figure 6 and 7 it should be noted that in room XXVIII, thanks to the control of temperature values, the seasonal RH variations are more flat. From Figure 8, as regards monthly PI $\theta$ values of rooms without a temperature control system, the most problematic periods appear to be the winter and the summer, during which the temperatures are always outside the range recommended by the conservators. The Figure highlights also the criticality for the 
conservation of the artifacts in room XVI and XIX due to the daily temperature variations, especially during summer period, than can cause important and permanent damages.

\section{Dynamic simulations of solar shading systems}

\subsection{Integrated solutions applied to room XVI and XIX}

As discussed in the previous paragraphs, the main problems of the Specola Museum concern the high values of temperature $(\theta)$ as well as the high daily variations of this parameter $(\Delta \theta 24)$ in summer period that are particularly hazardous for the proper conservation of the kind of objects exhibited. In order to control the temperature inside the analyzed rooms, different summer passive strategies are selected and discussed. In particular, solar shading devices, double glazing and solar control glasses has been selected and evaluated also in order to enhance the integration between windows and solar control devices in historical buildings that are often bonded by the Italian Ministry of Culture. Accordingly, the effectiveness of sun protection of glass surfaces depends on different factors, such as: the characteristics of the screen materials and coating over it (reflectance), the type of solar shading solution (fixed or mobile), the positioning of the screen with respect to the frame (external, internal, intermediate), the disposition of the screen according to the façade (parallel, orthogonal, horizontal, vertical, etc.), exposition, its geographical location and its thermal loads [11]. For the museum under investigation, some strategies, concerning both the replacement of the existing windows and the use of different solar shadings, has been selected and applied to the room XVI and the room XIX. In order to evaluate these strategies, a model of the two above mentioned rooms (as illustrated in Figure 9) was made in Energy Plus ${ }^{\circledR}$, trough the Design Builder ${ }^{\circledR}$ interface. In order to perform a more accurate calculation of the heat transfer through the high thermal inertia walls of the Museum, the conduction finite difference solution algorithm was used instead of the default conduction transfer functions and simulation time steps were set to 30 times per hour [12]. The hourly values of dry bulb temperature of the outside air and solar radiation for the Florence location are from the Institute "Gianni De Giorgio" archive (IGDG). Thermal properties of the opaque and transparent building elements, described in Table 3, correspond in the dynamic simulation to the existing building (case A). Other bound ary conditions, referred to occupant gains, lighting gains and infiltration are summarized in Table 4. On the basis of the results of previous research [13] and the architectural features of the analyzed rooms, in Tables 5 and 6 the selected strategies are described. The geometric and physical characteristics of both the shadings and the glasses used for the dynamic simulation have been selected among the common Italian market products. The different selected strategies were evaluated on the basis of their thermal performances by means of dry bulb temperature $\theta\left({ }^{\circ} \mathrm{C}\right)$, and the reduction seasonal factor of energy need for space cooling, Fs (\%). In particular, the reduction seasonal factors Fs [13] is expressed as a percentage and calculated as a complement to the unity of the ratio between the energy need for space cooling (from May 1st to October 15th) calculated on an hourly basis compared to those of the existing building (Case A).

\subsection{Results and discussion}

The effects on the reduction of summer thermal loads Fs resulting from the solutions adopted are shown in Figure 10 and 11 respectively for the rooms XVI and XIX. For room XVI, the following observations based on the value Fs can be made: D, E and F solutions are the most effective ones as reduce summer loads from $51 \%$ (D) to $42 \%(\mathrm{~F})$. When a double glazing is set, an external solar shading, such as venetian blind (D) or roller shade $(\mathrm{F})$, greatly reduce summer solar radiation; an effective alternative is the combination of solar control glazing with internal roller shade (E). Regarding room XIX, the most effective shadings are P, M and I that combine solar control glazing (I) to internal shadings, such as venetian blind (M) or roller shade (P), and reduce Fs from $51 \%$ (I) to $57 \%(\mathrm{P})$. Regarding the effectiveness in terms of Fs of external venetian blind (tilting $0^{\circ}$ ), for room XVI this solution (D) is the most effective, otherwise in room XIX the effectiveness of this solution (L) is not excellent because of the different orientation of the three windows that varies from SE to 
NW. In general, in the choice of a proper external solar shading devices has to take into account also costs and maintenance problems of the device itself (both on the roof skylights as well as on the façade) related for example to the highness of the building itself and its poor accessibility. Regarding these aspects, important especially for historical buildings, some consideration can be pointed out: the effectiveness of solar control glazing (C and I), easy to install, varies from $36 \%$ (room XVI) to $51 \%$ (room XIX) while the effectiveness of double glazing combined with internal roller drape (G and O) varies from $28 \%$ (room XVI) to $40 \%$ (room XIX). These strategies, besides a good technical feasibility, guarantee a good reduction of energy need for space cooling. Figures 12 and 13, respectively for the room XVI and XIX, show the effects of the different simulated solutions on the variation of internal dry bulb temperature in one of the hottest week in the summer period (from 11 to 17 July). The following observations, based on Figure 12, can be made for room XVI: all the analysed shading devices and solar control glazing $(C, D, E, F$ and $G)$ are able to reduce the maximum dry bulb temperature values respect the base case $\mathrm{A}$; the maximum reduction varies from $0.5^{\circ} \mathrm{C}$ obtained with double glazing (B) to $1.5^{\circ} \mathrm{C}$ obtained with all the other solutions; solar control glasses (C) are able to reduce the maximum dry bulb temperature of $1.3^{\circ} \mathrm{C}$. As shown in Figure 13 , for the room XIX the most effective solutions are those which combine a solar control glass with internal venetian blind $(\mathrm{M})$ or internal roller shade $(\mathrm{P})$; these solutions reduce the maximum dry bulb temperature values of up to $3^{\circ} \mathrm{C}$ respect the base case $\mathrm{A}$. Double glazing $(\mathrm{H})$ is able to reduce the maximum dry bulb temperature values of $1^{\circ} \mathrm{C}$, while for the solar control glass (I) this reduction arises to $2.5^{\circ} \mathrm{C}$.

\section{Conclusions}

The UNI EN 15757, for historical buildings, identifies as a priority passive interventions on the structures, aimed at reducing thermal loads (heat, light) and/or mass (vapor, pollutants) between the environment under control and the external environment. On year monitoring campaign carried out in the "La Specola" Museum of Florence pointed out some critical aspects: temperature and relative humidity conditions were not reasonably acceptable for the preservation of the kind of objects exhibited. In particular, for some representative uncontrolled rooms of the museum (XVI and XIX) the temperature and RH trend follows the outdoor climate, although very dampened in sudden hourly and daily changes. In spring and autumn indoor temperature and $\mathrm{RH}$ are within the recommended range, whereas in summer and in winter temperature is respectively above and below the limits. Regarding the controlled room (XXVIII), the fan coils system keeps constant temperature values and reduces indirectly RH variations, except when the system is not working: in these moments the values are aligned to those of the other rooms, nevertheless variations in the temperature values can also be due to the presence of an unlocked thermostat that can be easily reached by visitors. Particularly significant is the comparison between temperature values inside the room (XIX) and inside the showcase (XIXs): in summer they are similar while in winter showcase values are below those of the room being this showcase huddled on a not insulated and North oriented external wall. Moreover, although the showcases are not sealed, they reduce $\mathrm{RH}$ variations respect those of the rooms and guarantee a damping of $\mathrm{RH}$ changes greater then temperature ones. The $\mathrm{RH}$ trend inside the cases is related to the indoor temperature trend rather than to the outdoor RH variations. As regards monthly $\mathrm{PI} \theta$ values and monthly PI $\Delta \theta 24$ of rooms without a temperature control system, the most problematic periods appear to be the summer, during which the temperatures $(\theta)$ and the daily temperature variations $(\Delta \theta 24)$ are outside the range recommended by the conservators and are particularly hazardous for the proper conservation of the kind of objects exhibited. Different summer passive strategies (shading devices, double glazing and solar control glasses selected among the common Italian market products) has been applied to the room XVI and the room XIX, and has been evaluated, by a dynamic simulation, on the basis of dry bulb temperature $\theta\left({ }^{\circ} \mathrm{C}\right)$, and the reduction seasonal factor of energy need for cooling, Fs (\%). For room XVI, the following observations can be made: when a double glazing is set, an external solar shading, such as venetian blind (D) or roller shade (F), greatly reduce summer solar radiation; an effective alternative is the combination of solar control 
glazing with internal roller shade (E). Moreover all the analysed shading devices and solar control glazing are able to reduce the maximum dry bulb temperature values respect the base case A up to $1.5^{\circ} \mathrm{C}$ (D, E, F and G). Regarding room XIX, solar control glazing combined to internal shadings, such as venetian blind $(\mathrm{M})$ or roller shade $(\mathrm{P})$, can reduce Fs up to $57 \%(\mathrm{P})$. External venetian blind (tilting $0^{\circ}$ ) are more effective in terms of Fs for skylights (room XVI) than for vertical windows not south oriented (room XIX). The external $(\mathrm{N})$ roller shade guarantee an improvement of performance in terms of Fs from $40 \%$ to $49 \%$ in comparison with internal one $(\mathrm{O})$. For this room the mosteffective solutions are those which combine a solar control glass with internal venetian blind (M) or internal roller shade $(\mathrm{P})$; these solutions reduce the maximum dry bulb temperature values of up to $3^{\circ} \mathrm{C}$ respect the base case A. The choice of a proper external solar shading device has to take into account also costs and maintenance problems of the device itself related for example to the highness of the building itself and its poor accessibility, must be properly assessed; for this historical building museum the replacement of existing windows with double low emissivity glazing (C and I) besides a good technical feasibility, guarantee a good reduction of energy need for space cooling from $36 \%$ (room XVI) to $51 \%$ (room XIX), while the effectiveness of double glazing combined with internal roller shade ( $\mathrm{G}$ and $\mathrm{O}$ ) varies from $28 \%$ (XVI) to $40 \%$ (XIX). From previous analysis the most effective solutions for room XVI and room XIX were pointed out: in particular, for room XVI, the replacement of existing skylight with double glazing combined with external venetian blind (D) improves the seasonal (summer) PI $\theta$ value from $44 \%$ (base case A) to $51 \%$. As regard room XIX, the most effective solution is the replacement of the three existing windows with solar control glasses combined with internal roller shades $(\mathrm{P})$; this solution improves the seasonal (summer) PI $\theta$ value from $38 \%$ (base case A) to $54 \%$.

\section{Acknowledgment}

Thanks are due to Prof. G. Pratesi, Director of the Natural History Muse um of Florence, and all the Conservators of Zoology "La Specola" Section, for having facilitated this work.

\section{Nomenclature}

$\begin{array}{ll}\mathrm{g} & \text { Solar factor, }(-) \\ \mathrm{Fs} & \text { Reduction factor of summer thermal loads, }(\%) \\ \mathrm{PI} & \text { Performance Index, }(\%) \\ \mathrm{RH} & \text { Relative humidity, }(\%) \\ \mathrm{U} & \text { Thermal transmittance, }\left(\mathrm{W} / \mathrm{m}^{2} \mathrm{~K}\right) \\ \mathrm{Ug} & \text { Thermal transmittance of the glass, }\left(\mathrm{W} / \mathrm{m}^{2} \mathrm{~K}\right) \\ \mathrm{Uw} & \text { Thermal transmittance of the window, }\left(\mathrm{W} / \mathrm{m}^{2} \mathrm{~K}\right) \\ \theta & \text { Dry bulb temperature },\left({ }^{\circ} \mathrm{C}\right) \\ \Delta \theta 24 & \text { Daily gradient of temperature },\left({ }^{\circ} \mathrm{C}\right) \\ \Delta \mathrm{RH} 24 & \text { Daily gradient of relative humidity, }(\%) \\ \tau \mathrm{V} & \text { Light and solar transmittance, }(-)\end{array}$

\section{References}

[1] S.P. Corgnati, V. Fabi, M. Filippi, A methodology for microclimatic quality evaluation in museums: Application to a temporary exhibit, Building and Environment. 44 (2009) 1253-1260. doi:10.1016/j.buildenv.2008.09.012

[2] G. Thomson, The Museum Environment, Butterworths, London, 1986

[3] N. Stolow, Conservation and Exhibitions, Butterworths, London, 1987

[4] D. Camuffo, Microclimate for Cultural Heritage, Elsevier, Amsterdam, 1998

[5] G. Pavlogeorgatos, Environmental parameters in museums, Building and Environment. 38 (2003) 1457-1462. doi:10.1016/S0360-1323(03)00113-6. 
[6] M. La Gennusa, G. Rizzo, G. Scaccianoce, F. Nicoletti, Control of indoor environments in heritage buildings: experimental measurements in an old Italian museum and proposal of a methodology, Journal of Cultural Heritage. 6 (2005) 147-155. doi:10.1016/j.culher.2005.03.001.

[7] UNI, Works of art of historical importance. Ambient conditions for the conservation. Measurement and analysis. Italian Standard UNI 10829, 1999

[8] UNI EN, Conservation of Cultural Property. Specifications for temperature and relative humidity to limit climate induced mechanical damage in organic hygroscopic materials. European Standard UNI EN 15757, 2010

[9] J. Ferdyn-Grygierek, Indoor environment quality in the museum building and its effect on heating and cooling demand, Energy and Buildings. (2014). doi:10.1016/j.enbuild.2014.09.014.

[10] Ministero per i beni e le attività culturali, D.M. 10.5.2001 Atto di indirizzo sui criteri tecnicoscientifici e sugli standard difunzionamento e sviluppo dei musei, Italian Minister Degree G.U. n.238, 19.10.2001.

[11] C. Carletti, F. Sciurpi, L. Pierangioli, The Energy Upgrading of Existing Buildings:Window and Shading Device Typologies for Energy Efficiency Refurbishment, Sustainability. 6 (2014) 53545377. doi:10.3390/su6085354.

[12] S. Carlucci, Thermal Comfort Assessment of Buildings, Springer, Milan, 2013

[13] G. Cellai, C. Carletti, F. Sciurpi, S. Secchi, Transparent Building Envelope: Windows and Shading Devices Typologies for Energy Efficiency Refurbishments, in: A. Magrini (Ed.), Building Refurbishment for Energy Performance, Springer International Publishing, Berlin, 2014: pp. 61-118.

\section{Figures and Tables}

Figure 1 - Floor plan of the museum with the monitoring system

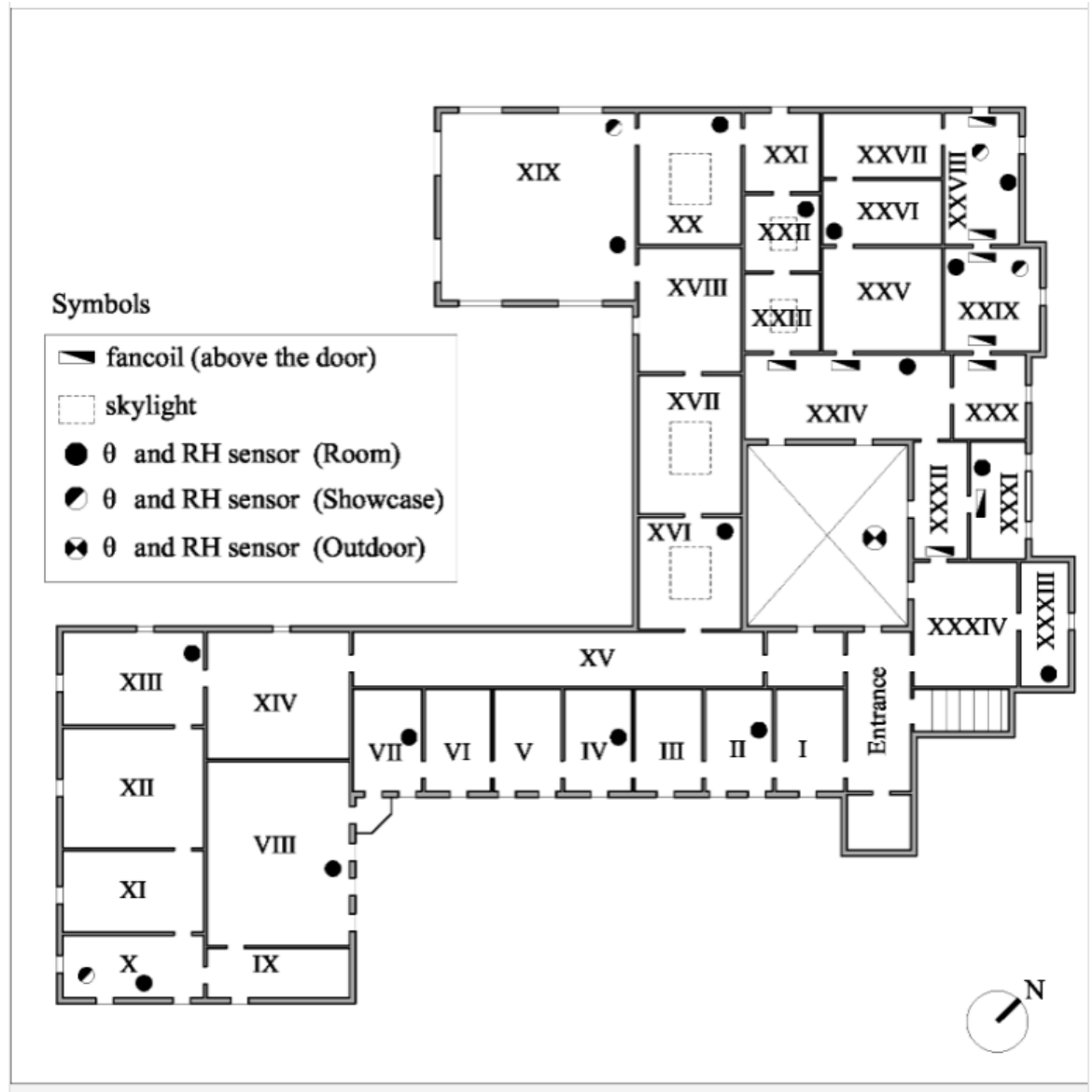

Table 1 - Main characteristics of the analysed Rooms 


\begin{tabular}{|c|c|c|}
\hline Room XVI & $\begin{array}{l}\text { Objects exposed: } \\
\text { Italian birds stuffed }\end{array}$ & $\begin{array}{l}\text { Technical systems: } \\
\text { - No HVAC system } \\
\text { - Direct artificial lighting of the room with tubular } \\
\text { fluorescent lamps } \\
\text { - No light inside showcases }\end{array}$ \\
\hline & $\begin{array}{l}\text { Room dimensions: } \\
\text { Plant surface (m2): } 54 \\
\text { Volume (m3): } 224\end{array}$ & $\begin{array}{l}\text { Architectural features: } \\
\text { - One skylight without external solar shading } \\
\text { - Two external walls (SW and NE oriented) and } \\
\text { not insulated pitched roof }\end{array}$ \\
\hline \multirow[t]{2}{*}{ Room XIX } & $\begin{array}{l}\text { Objects exposed: } \\
\text { Large birds stuffed }\end{array}$ & $\begin{array}{l}\text { Technical systems: } \\
\text { - No HVAC system } \\
\text { - Direct artificial lighting of the room with tubular } \\
\text { fluorescent lamps } \\
\text { - Direct artificial lighting inside showcases with } \\
\text { tubular fluorescent lamps }\end{array}$ \\
\hline & $\begin{array}{l}\text { Room dimensions: } \\
\text { Plant surface (m2): } 171 \\
\text { Volume (m3): } 1148\end{array}$ & $\begin{array}{l}\text { Architectural features: } \\
\text { - Six large windows (two SE, two SW and two NW } \\
\text { oriented) without external solar shading } \\
\text { - Three external walls (SE, SW and NW oriented) } \\
\text { and not insulated pitched roof }\end{array}$ \\
\hline \multirow[t]{2}{*}{ Room XXV } & $\begin{array}{l}\text { Objects exposed: } \\
\text { Anatomical waxes }\end{array}$ & $\begin{array}{l}\text { Technical systems: } \\
\text { - Fan coils system to control air temperature } \\
\text { - Direct artificial lighting of the room with tubular } \\
\text { fluorescent lamps } \\
\text { - No light inside showcases }\end{array}$ \\
\hline & $\begin{array}{l}\text { Room dimensions: } \\
\text { Plant surface (m2): } 46 \\
\text { Volume (m3): } 164\end{array}$ & $\begin{array}{l}\text { Architectural features: } \\
\text { - Two windows (one NW and one NE oriented) } \\
\text { with external persian shutters } \\
\text { - Two external walls (NW and NE oriented) and } \\
\text { not insulated pitched roof }\end{array}$ \\
\hline
\end{tabular}

Figure 2 - Time profile of mean daily temperature values for one year monitoring period.

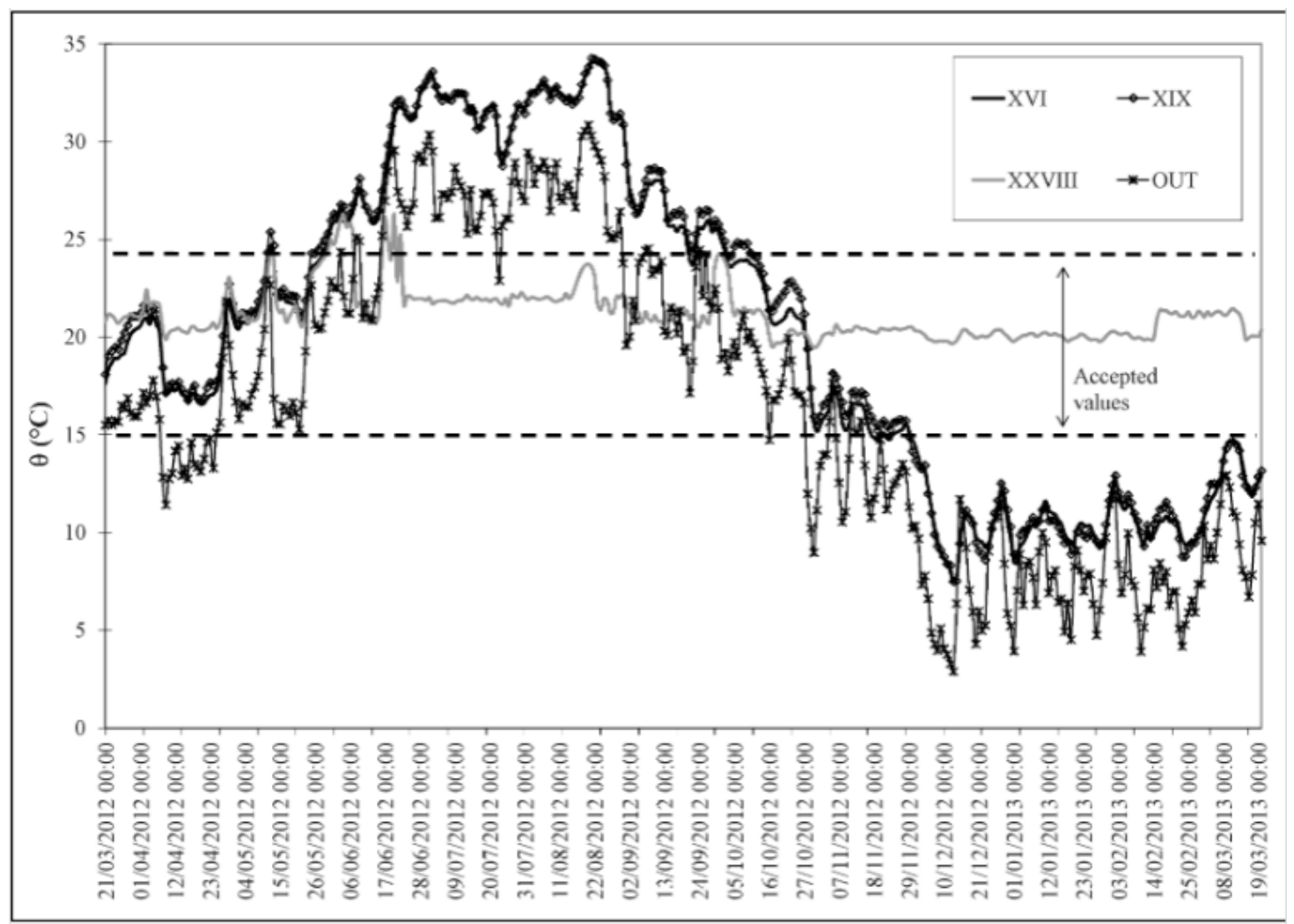

Figure 3 - Time profile of mean daily RH values for one year monitoring period. 


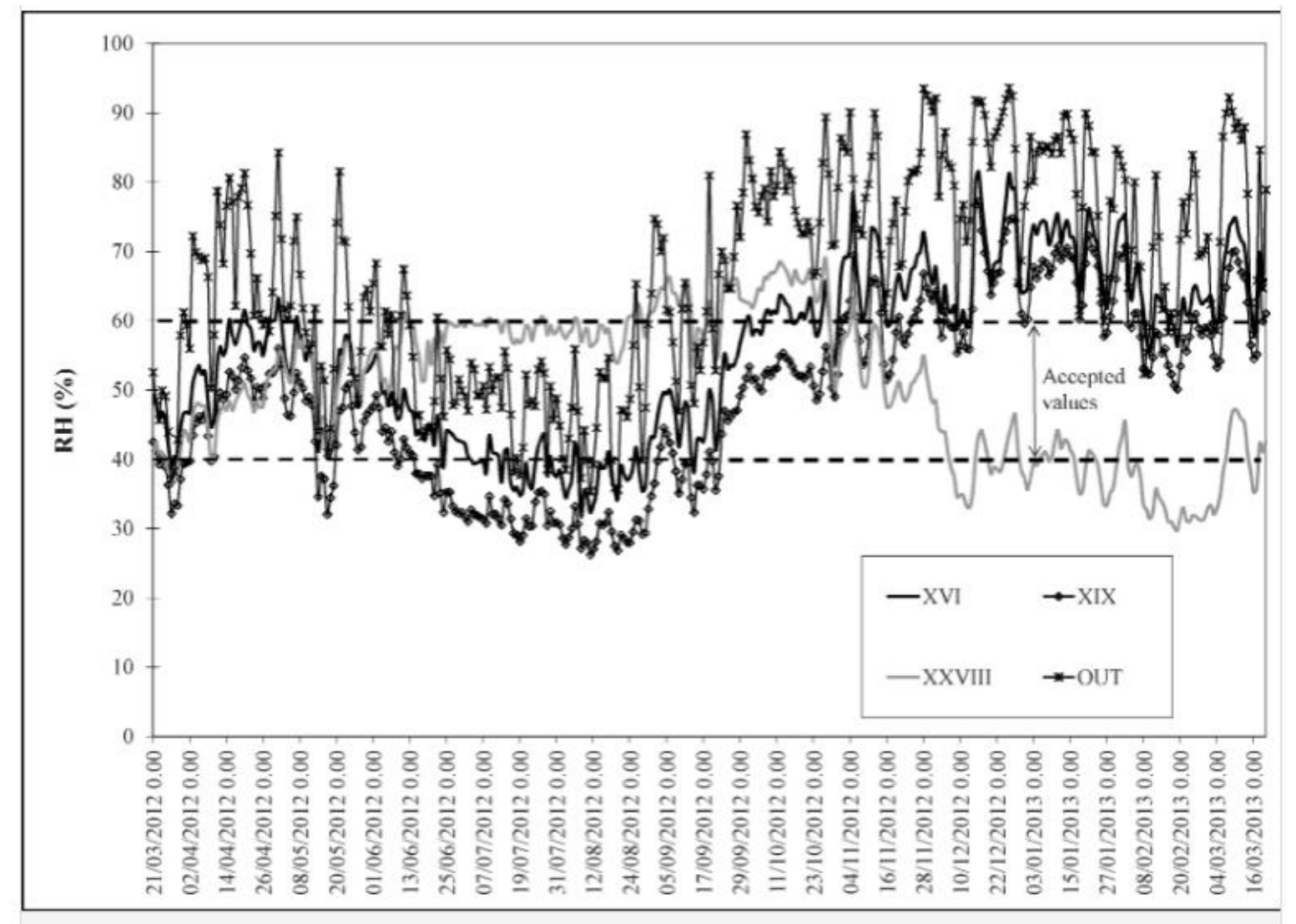

Table 2 - Maximum daily gradient and PI of thermo hygrometric parameters.

\begin{tabular}{|l|l|l|l|l|l|l|}
\hline Environment & XVI & XIX & XIXs & XXVIII & XXVIIIs & OUT \\
\hline$\Delta \theta_{24 \max }$ & $3.8^{\circ} \mathrm{C}$ & $4.7^{\circ} \mathrm{C}$ & $3.6^{\circ} \mathrm{C}$ & $6.6{ }^{\circ} \mathrm{C}$ & $7.2{ }^{\circ} \mathrm{C}$ & $22.6^{\circ} \mathrm{C}$ \\
\hline$\Delta \mathrm{RH}_{24} \max$ & $20 \%$ & $18 \%$ & $7 \%$ & $15 \%$ & $4 \%$ & $63 \%$ \\
\hline $\mathrm{PI}_{\hat{\sigma}}$ & $32 \%$ & $32 \%$ & $30 \%$ & $95 \%$ & $95 \%$ & - \\
\hline $\mathrm{PI}_{\mathrm{RH}}$ & $47 \%$ & $47 \%$ & $41 \%$ & $60 \%$ & $71 \%$ & - \\
\hline $\mathrm{PI}_{\triangle 624}$ & $46 \%$ & $15 \%$ & $26 \%$ & $63 \%$ & $62 \%$ & - \\
\hline $\mathrm{PI}_{\triangle \mathrm{RH} 24}$ & $63 \%$ & $65 \%$ & $99 \%$ & $67 \%$ & $100 \%$ & - \\
\hline
\end{tabular}

Figure 4 - Time profile of temperature values for the coldest week of the year monitored. 


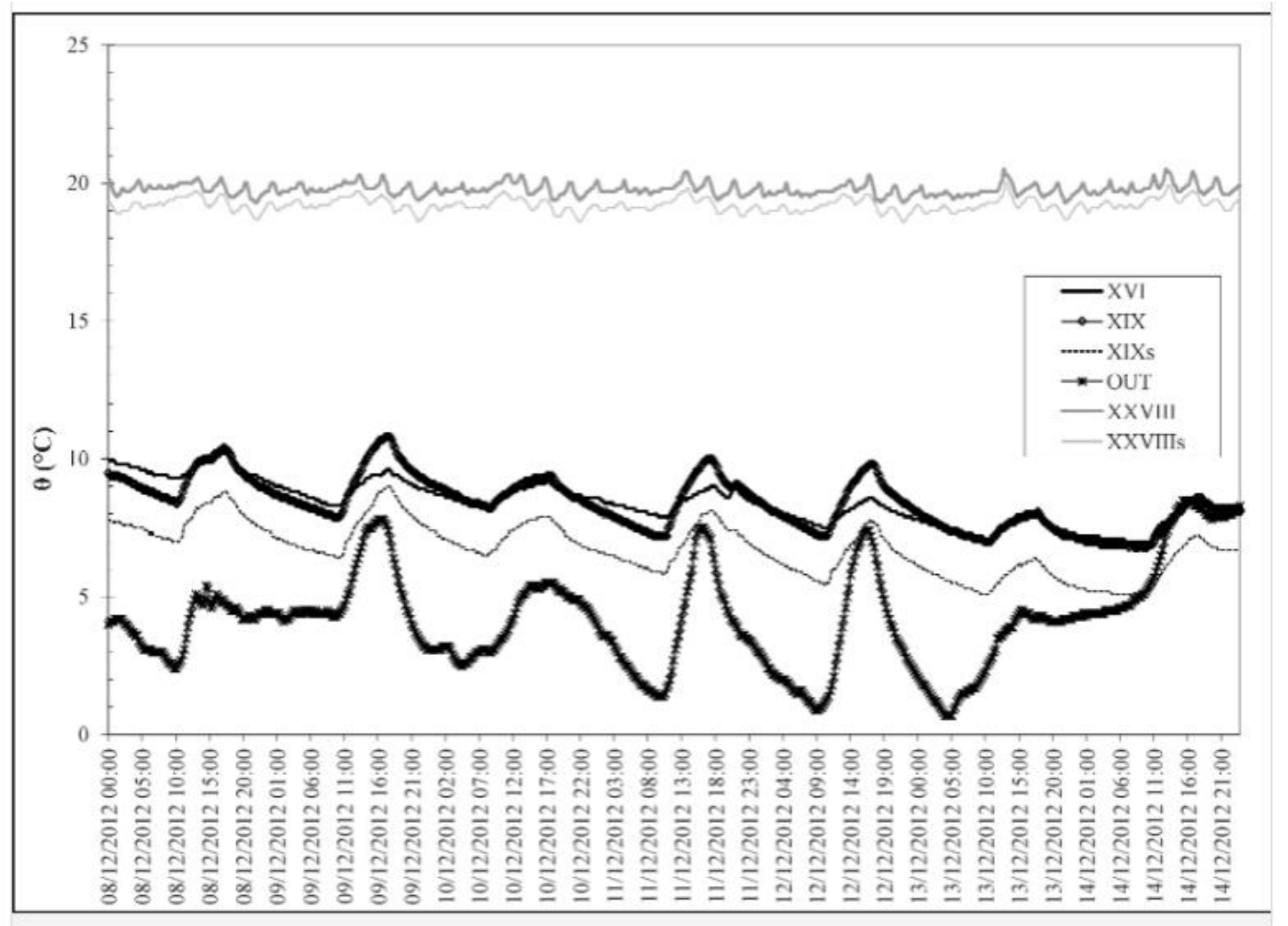

Figure 5 - Time profile of temperature values for the hottest week of the year monitored.

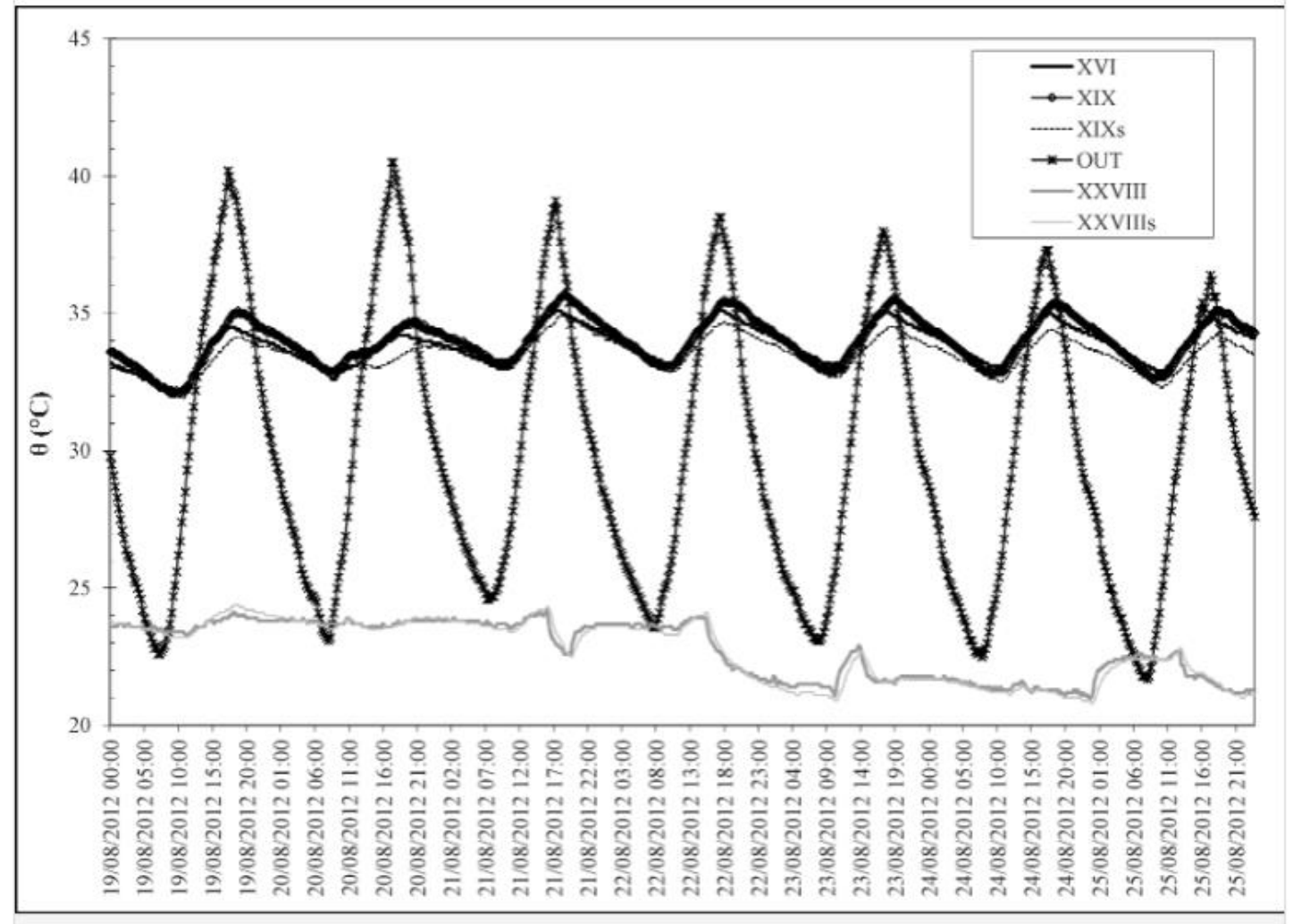


Figure 6 - Time profile of RH values of the year monitored for the room XIX and the showcase XIXs

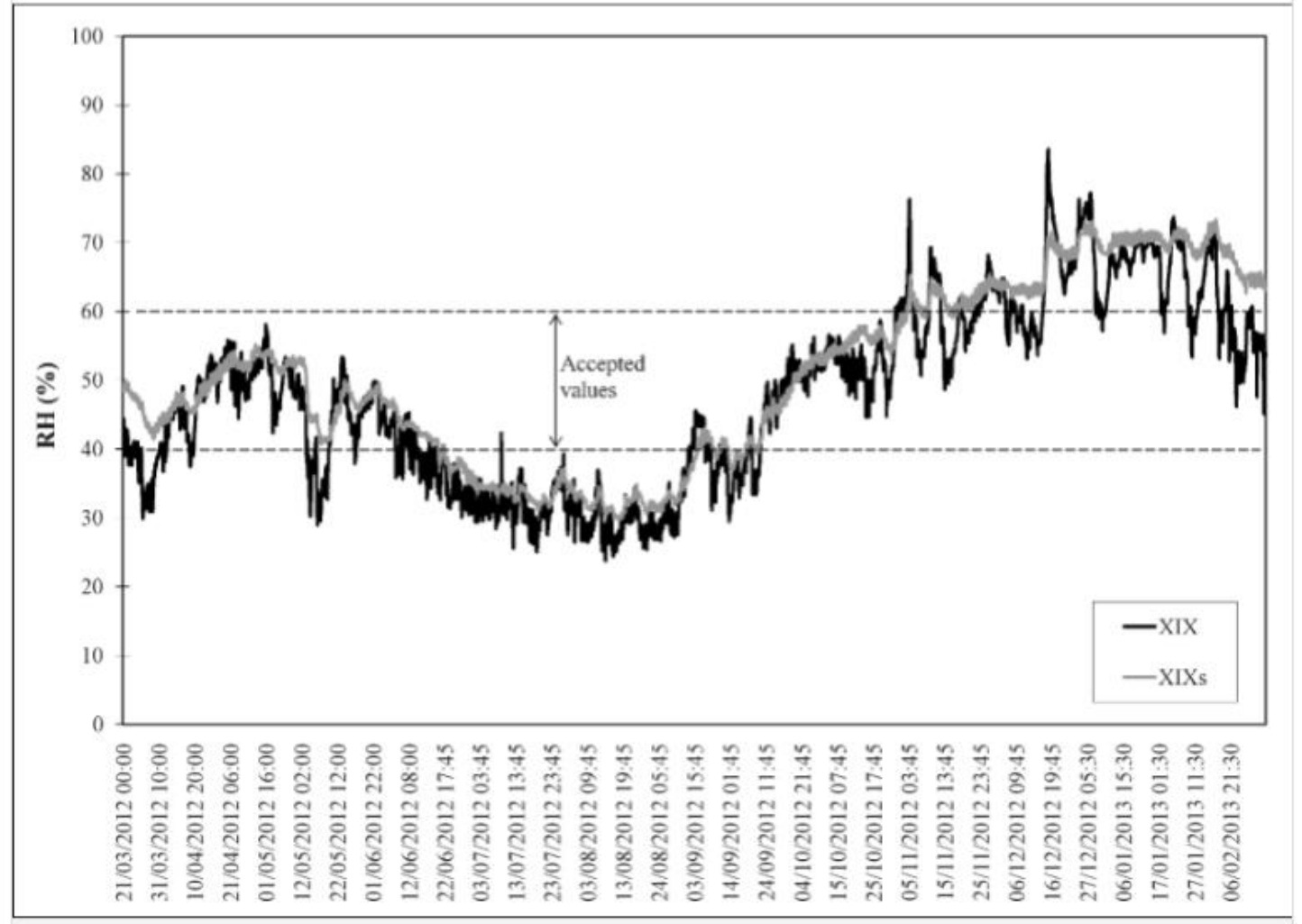

Figure 7 - Time profile of RH values of the year monitored for the room XXVIII and the showcase XXVIIIs

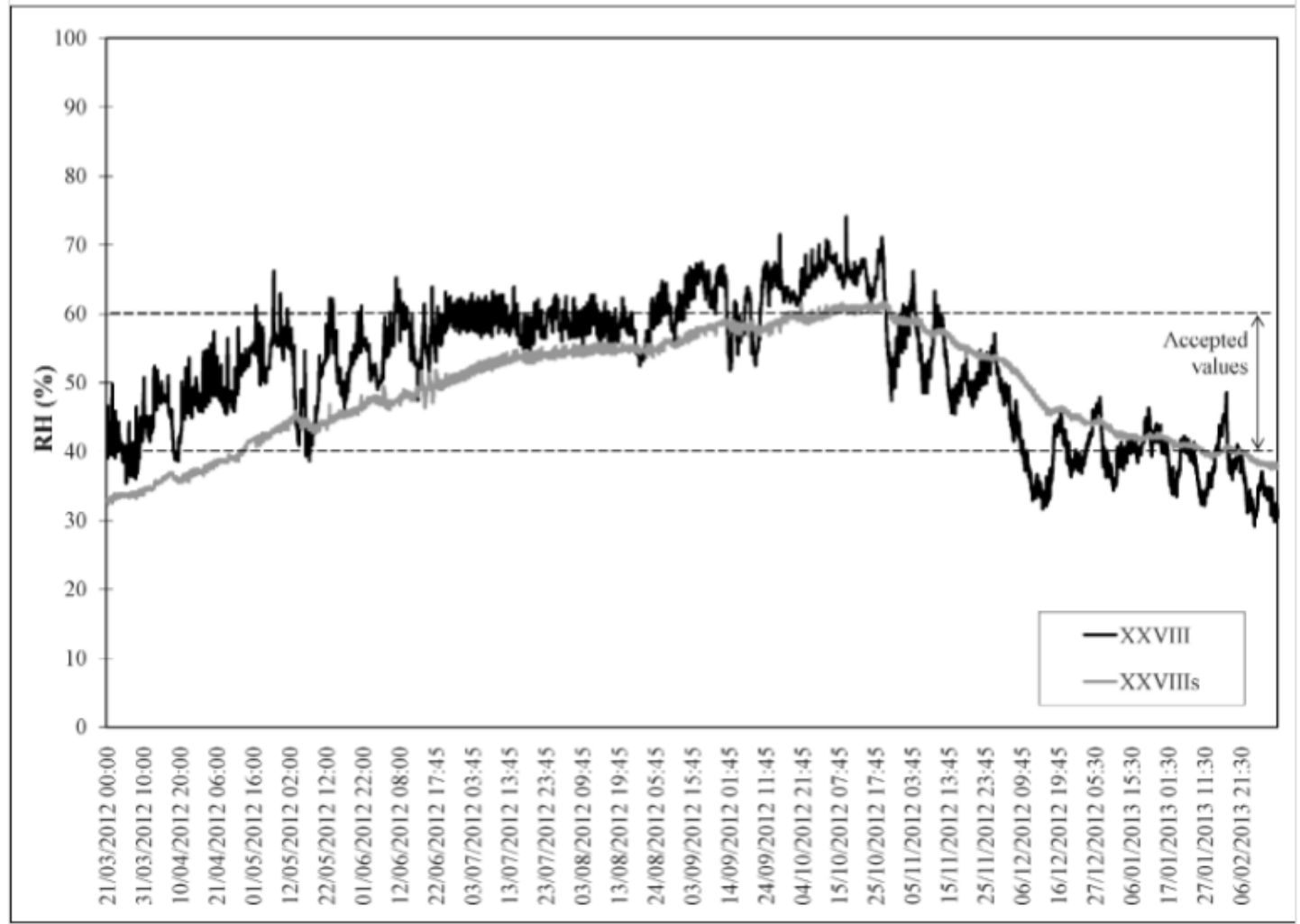


Figure 8 - Monthly PI $\theta$ and PI $\Delta \theta 24$ calculated values of rooms without temperature control system (XVI, XIX, XIXs)

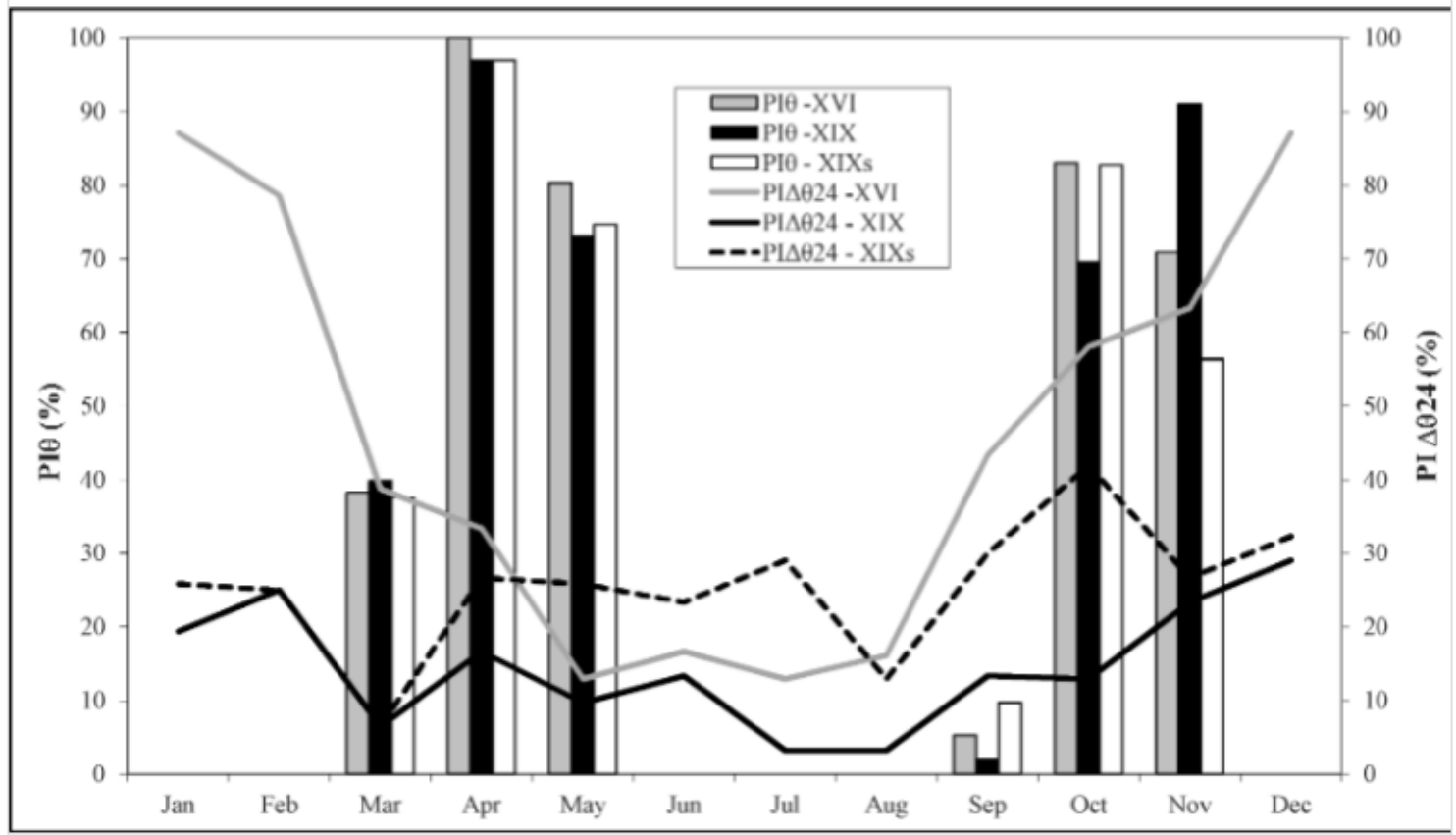

Figure 9 - Plan and section of the two analysed rooms.

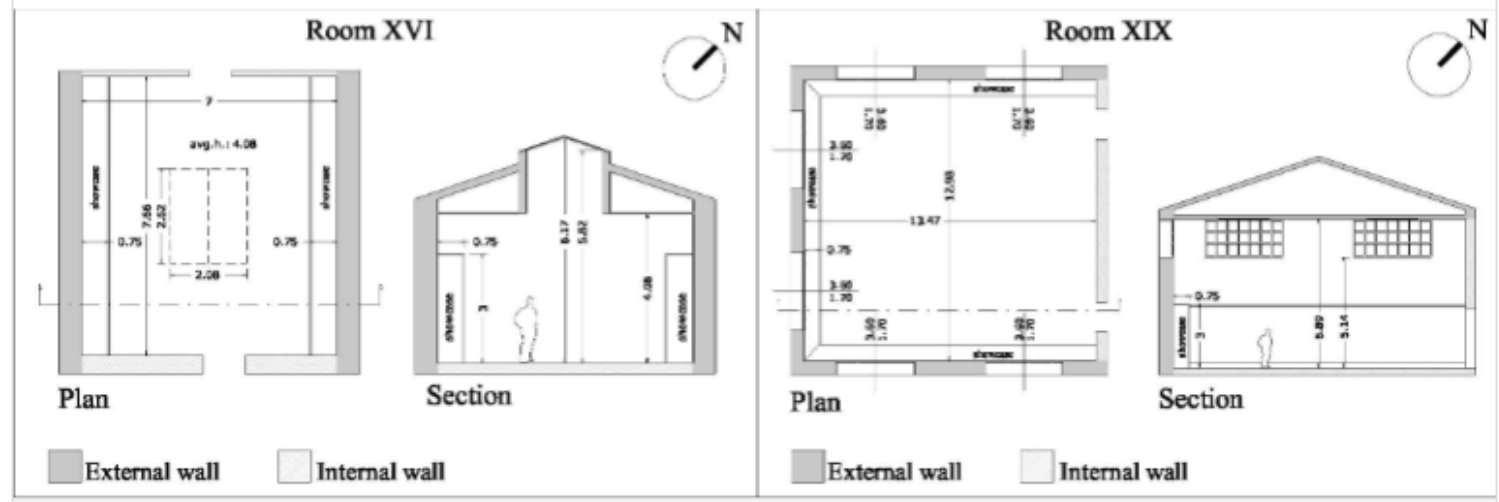

Table 3 - Thermal and optical properties of the existing building envelope

\begin{tabular}{|c|c|c|c|c|}
\hline $\begin{array}{l}\text { Building } \\
\text { element }\end{array}$ & Description & \multicolumn{2}{|c|}{ Thickness (m) } & $\mathrm{U}\left(\mathrm{W} / \mathrm{m}^{2} \mathrm{~K}\right)$ \\
\hline External wall & $\begin{array}{l}\text { Internal plaster }(0.02 \mathrm{~m}) \text {, stone blocks }(0.2 \mathrm{~m}) \text {, concrete } \\
\text { filling }(0.19 \mathrm{~m}) \text {, stone blocks }(0.2 \mathrm{~m}) \text {, external plaster }(0.02 \\
\mathrm{m})\end{array}$ & \multicolumn{2}{|c|}{0.63} & 1.53 \\
\hline False ceiling & Lime plaster $(0.01 \mathrm{~m})$, reed trellis $(0.01 \mathrm{~m})$ & \multicolumn{2}{|c|}{0.02} & 3.42 \\
\hline Roof & Wood rafters, brick tiles $(0.03 \mathrm{~m})$, roof tiles $(0.02 \mathrm{~m})$ & \multicolumn{2}{|c|}{0.05} & 2.99 \\
\hline & & $\begin{array}{c}\text { g-value } \\
(-)\end{array}$ & $\tau_{\mathrm{v}}(-)$ & $\mathrm{U}_{\mathrm{w}}\left(\mathbf{W} / \mathrm{m}^{2} \mathrm{~K}\right)$ \\
\hline Skylight & $\begin{array}{l}\text { Metal frame without thermal break (frame: } 0.01 \mathrm{~m} \text { wide - } \\
0.02 \mathrm{~m} \text { thick; dividers: } 0.04 \mathrm{~m} \text { wide }-0.02 \mathrm{~m} \text { thick); Single } \\
\text { clear glass ( } 3 \mathrm{~mm} \text { ) }\end{array}$ & 0.87 & 0.90 & 5.83 \\
\hline Windows & $\begin{array}{l}\text { Wood frame ( } 0.06 \mathrm{~m} \text { wide }-0.05 \mathrm{~m} \text { thick); Single clear } \\
\text { glass }(3 \mathrm{~mm})\end{array}$ & 0.87 & 0.90 & 4.96 \\
\hline
\end{tabular}


Table 4 - Boundary conditions: occupants and lighting gains and infiltrations

\begin{tabular}{|l|l|}
\hline Museum opening hours & $\begin{array}{l}\text { Winter: } 9: 30-16: 30, \text { from Tuesday to Sunday - Summer: 10:30-17:30, from Tuesday to } \\
\text { Sunday }\end{array}$ \\
\hline ROOM XVI & $\begin{array}{l}\text { Winter: } 0.36 \mathrm{p} / \mathrm{m}^{2} \text { every } 20 \text { minutes for } 10 \text { minutes - Summer: } 0.12 \mathrm{p} / \mathrm{m}^{2} \text { constant during } \\
\text { opening hours }\end{array}$ \\
\hline Occupants gain & $7.02 \mathrm{~W} / \mathrm{m}^{2}$ during opening hours \\
\hline Lighting gain & Yearly average value: 0.08 ach \\
\hline Infiltration & $\begin{array}{l}\text { Winter: } 0.12 \mathrm{p} / \mathrm{m}^{2} \text { every } 20 \text { minutes for } 10 \text { minutes - Summer: } 0.04 \mathrm{p} / \mathrm{m}^{2} \text { constant during } \\
\text { opening hours }\end{array}$ \\
\hline ROOM XIX & $9.50 \mathrm{~W} / \mathrm{m}^{2}$ during opening hours \\
\hline Occupants gain & Yearly average value: 0.11 ach \\
\hline Lighting gain &
\end{tabular}

Table 5 - Integrated solutions applied to room XVI

\begin{tabular}{|c|c|c|}
\hline Solution & Scheme & Description \\
\hline B & & $\begin{array}{l}\text { Replacement of existing windows with double low emissivity glazing; } \\
\mathrm{U}_{\mathrm{g}}=1.66 \mathrm{~W} / \mathrm{m}^{2} \mathrm{~K}, \mathrm{U}_{\mathrm{w}}=2.38 \mathrm{~W} / \mathrm{m}^{2} \mathrm{~K}, \mathrm{~g}=0.62, \tau_{\mathrm{v}}=0.79\end{array}$ \\
\hline $\mathrm{C}$ & & $\begin{array}{l}\text { Solar control glass: } \mathrm{U}_{\mathrm{g}}=1.66 \mathrm{~W} / \mathrm{m}^{2} \mathrm{~K}, \mathrm{U}_{\mathrm{w}}=2.38 \mathrm{~W} / \mathrm{m}^{2} \mathrm{~K}, \mathrm{~g}=0.21, \tau_{\mathrm{v}} \\
=0.40\end{array}$ \\
\hline D & & $\begin{array}{l}\left.\text { Solution B }+ \text { external venetian blind (tilting: } 0^{\circ}\right) \\
\text { Slat width }=0.080 \mathrm{~m} \text {, slat separation }=0.080 \mathrm{~m} \text {, blind-to-glass distance } \\
=0.1 \mathrm{~m} ;\end{array}$ \\
\hline $\mathrm{E}$ & & $\begin{array}{l}\text { Solution } \mathrm{C}+\text { internal roller shade; Shade-to-glass distance }=0.2 \mathrm{~m} \text {, } \\
\text { visible and solar transmittance }=0.4 \text {, visible and solar reflectance }= \\
0.45 \text {. }\end{array}$ \\
\hline $\mathrm{F}$ & & $\begin{array}{l}\text { Solution B + external roller shade; Shade-to-glass distance }=0.05 \mathrm{~m} \text {, } \\
\text { visible and solar transmittance }=0.4 \text {, visible and solar reflectance }= \\
0.45 \text {. }\end{array}$ \\
\hline G & & $\begin{array}{l}\text { Solution } B+\text { internal roller shade; Shade-to-glass distance }=0.2 \mathrm{~m} \text {, } \\
\text { visible and solar transmittance }=0.4 \text {, visible and solar reflectance }= \\
0.45\end{array}$ \\
\hline
\end{tabular}


Table 6 - Integrated solutions applied to room XIX

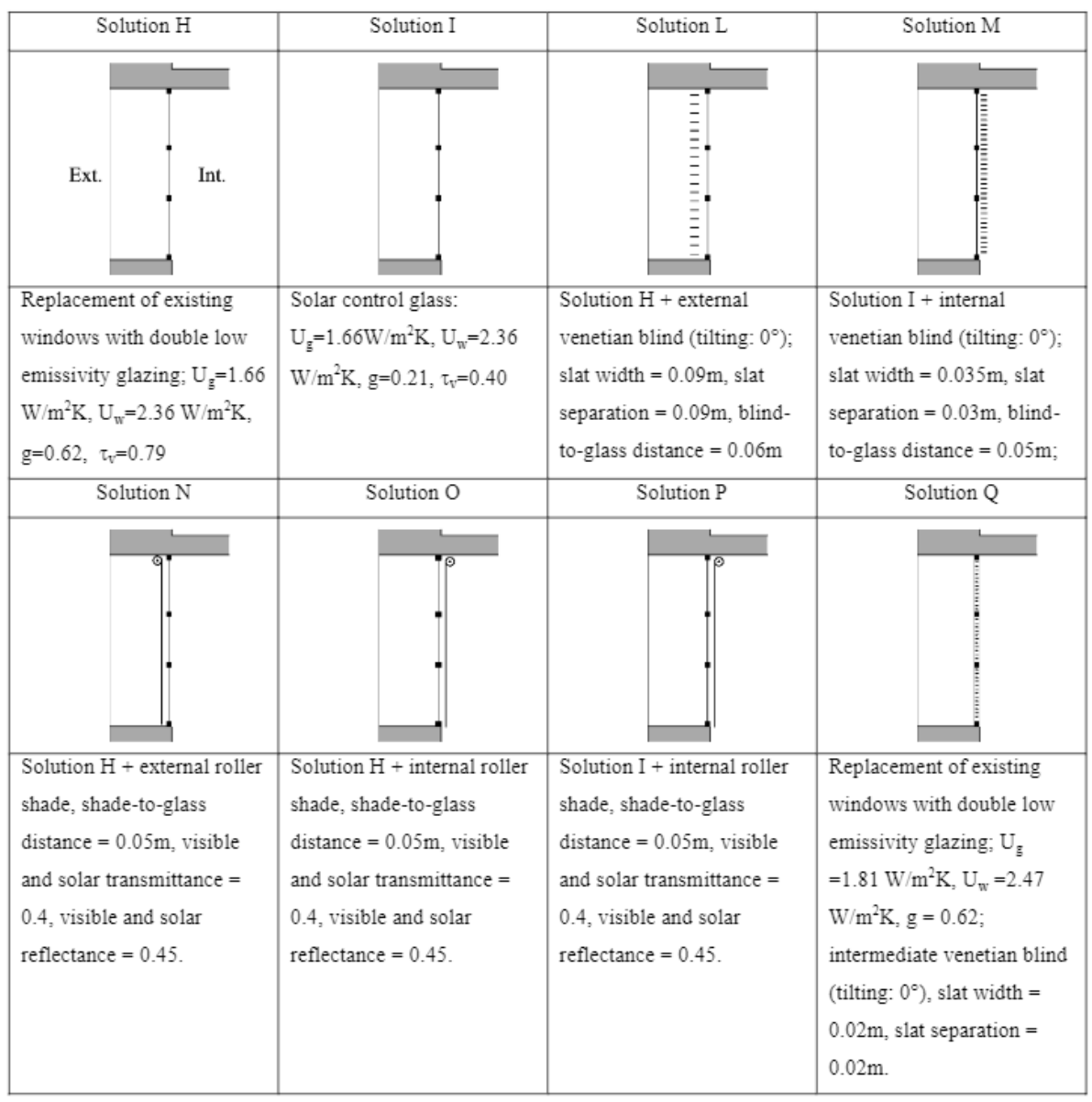

Figure 10 - Reduction of summer thermal loads Fs for room XVI.

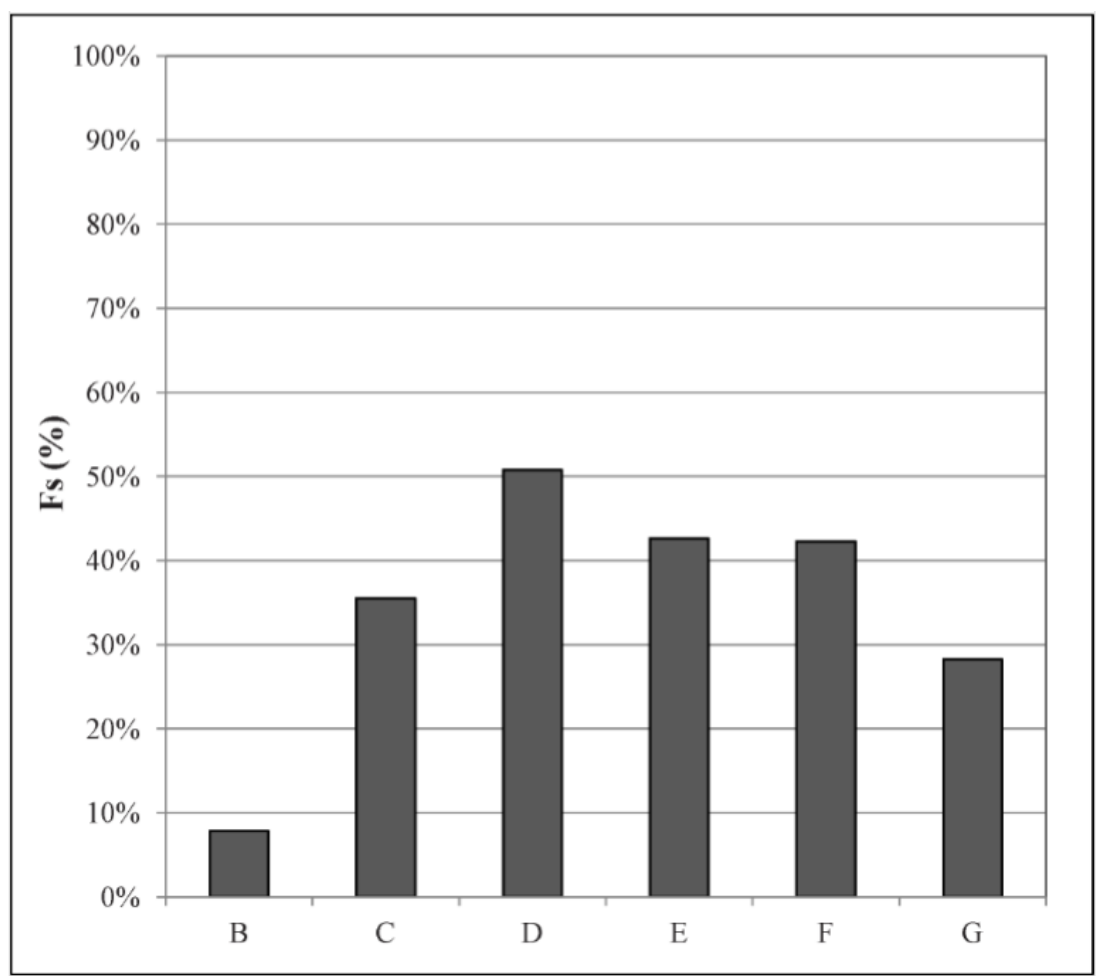


Figure 11 - Reduction of summer thermal loads Fs for room XIX.

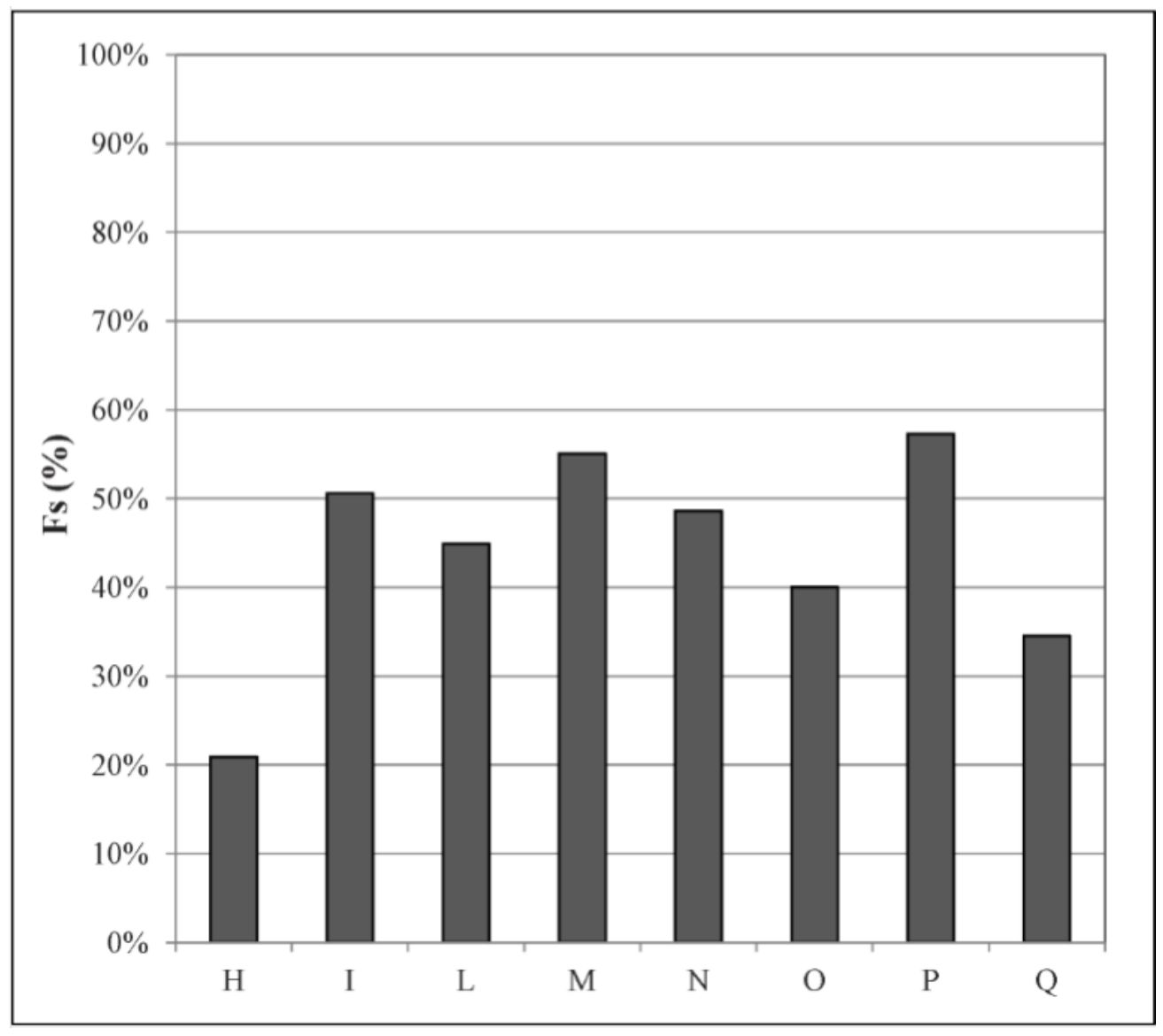

Figure 12 - Variation of internal dry bulb temperature from 11 to 17 July in room XVI.

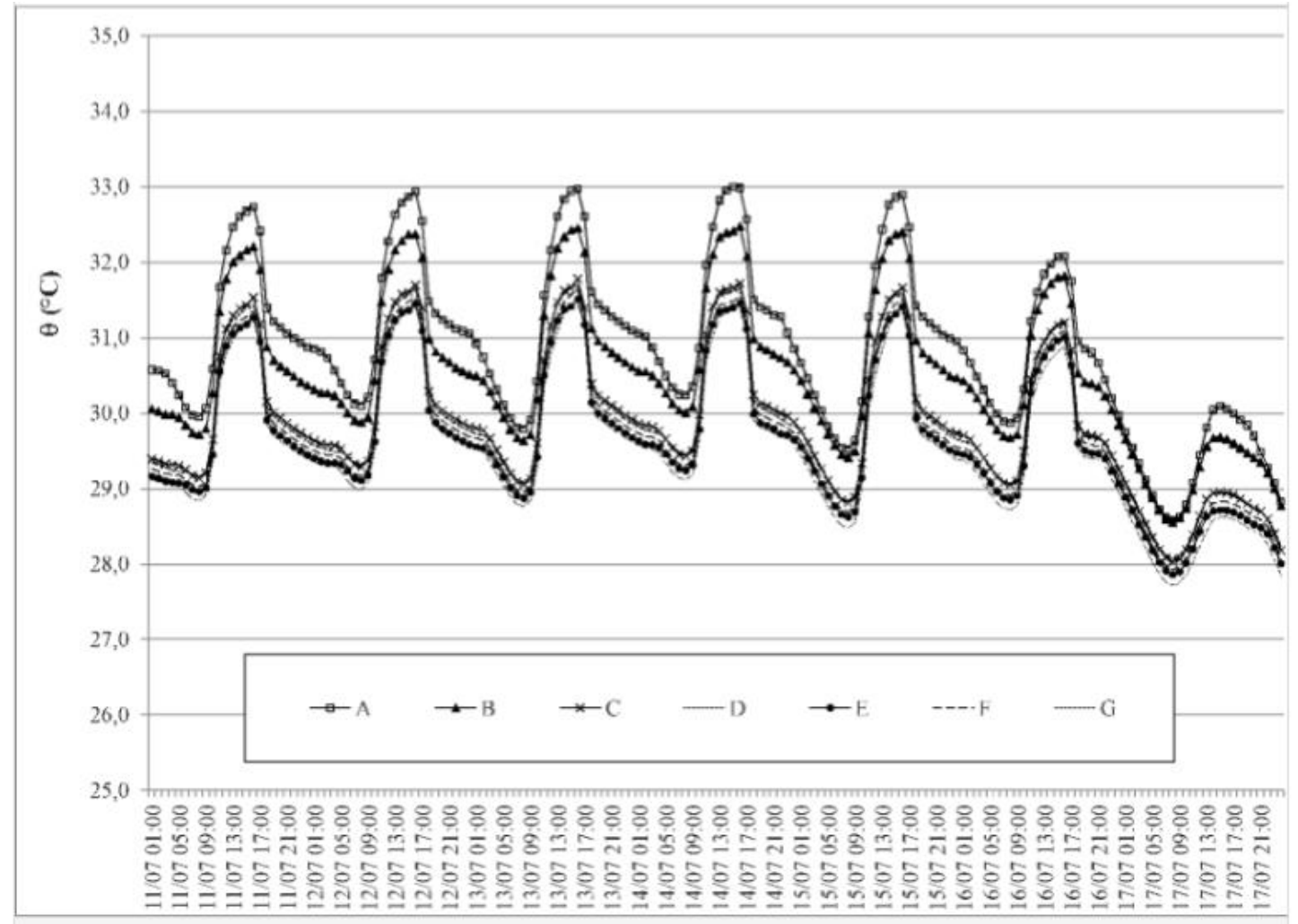


Figure 13 - Variation of internal dry bulb temperature from 11 to 17 July in room XIX

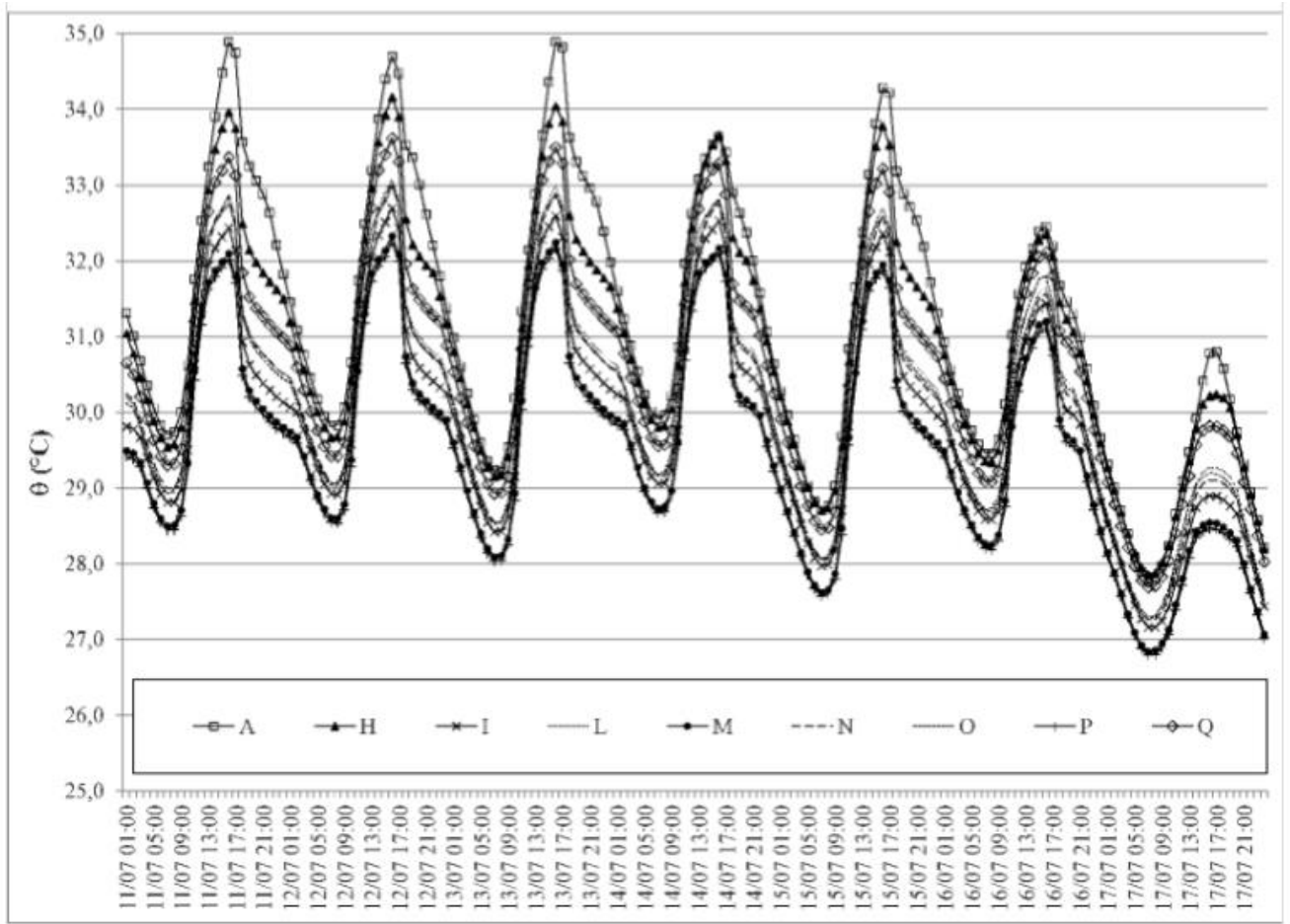

